\title{
Reese-Ellsworth Classification Group IV
}

National Cancer Institute

\section{Source}

National Cancer Institute. Reese-Ellsworth Classification Group IV. NCI Thesaurus. Code

C123366.

Unfavorable for maintenance of sight. 